\title{
Information literacy at school level: A comparative study between the Netherlands and South Africa
}

\author{
A.K. Boekhorst \\ Universiteit van Amsterdam, Archives and Information Science \\ Turfdraagsterpad 9, I0I 2 XT Amsterdam, The Netherlads \\ a.k.boekhorst@uva.nl
}

and

J.J. Britz

Department of Information Science, University of Pretoria

Britz@postino.up.ac.za

Received: 18 November 2003

Revised: 22nd December 2003

This article investigates, on a comparative basis, the current status of information literacy at school level in both the Netherlands and in South Africa. It is argued that information literacy has become one of the most important skills in the information society and that governments have a specific responsibility towards their citizens to prepare them for the challenges posed by the era in which we are living. The concept of information literacy is introduced and the link between information literacy and information education is illustrated. The current Dutch and South African educational systems are discussed from an information literacy perspective. It is concluded that both governments understand the importance of information literacy, but still focus on ICT literacy. It is furthermore argued that libraries can play an important role in the introduction of information literacy at school level.

\section{Introduction}

There is general agreement in the academic literature that we are currently living in the so-called information era. It is however clear that there is no standard definition of the information era and that the information society means different things to different people and is described amongst other as 'post-industrial society', 'information societies', 'knowledge societies', or 'network society' and more recently 'experience societies' (Webster, 2002:21).

However, three common themes dominate the recent era. These can be summarised as follows:

- Information and knowledge have become the most important assets of society.

- The primary economic questions no longer deal with scarcity, but focus on the management of the abundance of information which has become available as a result of technology (Dumort \& Fenoulhet 1997). This can be seen as the introduction of advanced capitalism and the globalisation of the economy (Stiglitz, 200 I). According to Grulke (1997) this economic model has shifted from 'the economics of scarcity' to 'the economics of plenty'. Hand in hand with this goes the emphasis on the exchange value of information versus its use-value (Lyotard, 1984).

- The rapid development of information and communication technologies (ICT) has become the engine in the process of globalisation.

In this process access to information and the use of information technology have become the most important criteria for this new form of advanced capitalism. Those who 'know' and those who 'don't know' are therefore categorised according to these criteria. Rifkin justly expresses this distinction, stating that

the information and telecommunication technologies and global market forces are fast polarizing the world's population into two irreconcilable and potentially warring forces - a new cosmopolitan elite of 'symbolic analysts' who control the technologies and the forces of production, and the growing number of permanently displaced workers who have little hope and even fewer prospects for meaningful employment in the new high tech global economy (1995: xvii).

This concept has contributed to the perception that communities who do not have access to modern ICT and who are not able to access and use relevant information, do not form part of the global information economy and are therefore regarded as information poor (Kingma, 200I: 97 ; Britz \& Blignaut, 200I: 64).

Therefore, to be able to function adequately in a society that is oriented towards information and ICT, people need to become more information literate than ever before. These skills are partly learned in daily life but ought to be a part of the school curriculum for systematic learning. National governments have a specific responsibility here, as they determine the content and form of the educational system in which pupils are prepared for their future lives as responsible and participative citizens (Swaan, 1988: I). 
To prepare their citizens for successful lives in the globalised information society both the Netherlands and South Africa emphasise the importance of life-long-learning, which includes information literacy programs and ICT training. The question remains, however: is the current education in both the Netherlands and South Africa adequate to enable people to become information literate? This question introduces the purpose of this article. What is the reason for comparing these two countries?

The reasons for comparing the two countries are threefold. The first is that both countries value the importance of ICT for development, secondly that the Netherlands presents a developed first world country and South Africa represents a developing country (which would make a comparison rather interesting), and thirdly that the one author resides in the Netherlands and the other in South Africa.

The article will be structured in the following manner. First it will introduce the notion of information literacy, emphasising its importance for the information society. This description will create the basis for the second part, in which current state of information literacy programmes at school level in the Netherlands and South Africa will be explored. The article ends with a conclusion and summary of findings.

\section{Information literacy}

The term 'information skills' was first introduced in 1974 by Zurkowski to refer to people who are able to solve their information problems by using relevant information sources and applying relevant technology (Zurkowski, 1974). The concept has evolved since then and the most appropriate definition is offered by the American Library Association, which defines it in the Final Report of the American Library Association Presidential Committee on Information Literacy:

To be information literate, a person must be able to recognize when information is needed and have the ability

to locate, evaluate, and use effectively the needed information (American Library Association, 1989).

Based on this definition of information literacy it can be stated that information literate people are those who have learned how to learn. They know how to learn because they know how knowledge is organised, how to find information and how to use information in such a way that others can learn from them (Foster, 1993: 344). It furthermore enables individuals to recognise the value of information and use it to make informed choices in their professional, social and personal lives by developing the skills to search, find and use information effectively.

Information literacy also implies the knowledge of how to use the various technologies, be it information and communication technologies or others, to gain access to and retrieve relevant information. It is important to emphasise the fact that knowledge of ICT alone does not constitute information literacy. ICT or computer literacy can only be seen as one of the elements of information literacy.

Since the introduction of the term 'information literacy' the concept has been widely discussed. In the 1980s and 1990s the term moved away from user education and library instruction in school contexts towards a broader context, and for some years has meant a concept of competences needed for learning to learn and social responsibility. All definitions and descriptions presented over the years can be summarised in three concepts:

I. The ICT concept. Information literacy refers to the competence to use ICT to retrieve and disseminate information.

2. The information (re)sources concept. Information literacy refers to the competence to find and use information independently or with the aid of intermediaries.

3. The information process concept. Information literacy refers to the process of recognising information needs, the retrieving, evaluating, use and dissemination of information to acquire or extend knowledge.

The third option, however, is the most comprehensive and most useful one, as this concept includes both ICT and the information (re)sources concept. In this concept humans are considered as information systems that retrieve, evaluate, process and disseminate information to make decisions in order to survive, for self-actualisation and development.

At the same time, information literacy is not a static, but a dynamic concept. It is adapted continually to keep up with the demands in different historical, economic, social, cultural and technological contexts. When it was first introduced by Zurkowski, it referred to the application of information resources in a work environment. After a period of emphasis on information use in a school environment the use has extended to competences needed in every phase in a person's life and in every context worldwide. It should also be noted that while people mature physically from childhood to infancy to adolescence; they also develop their minds, enabling the understanding of abstract thinking and mathematical reasoning. As they reach full maturity, ethical aspects become relevant.

The process to locate, access, retrieve, use and disseminate information (information literacy) can be visually represented in the following model: 


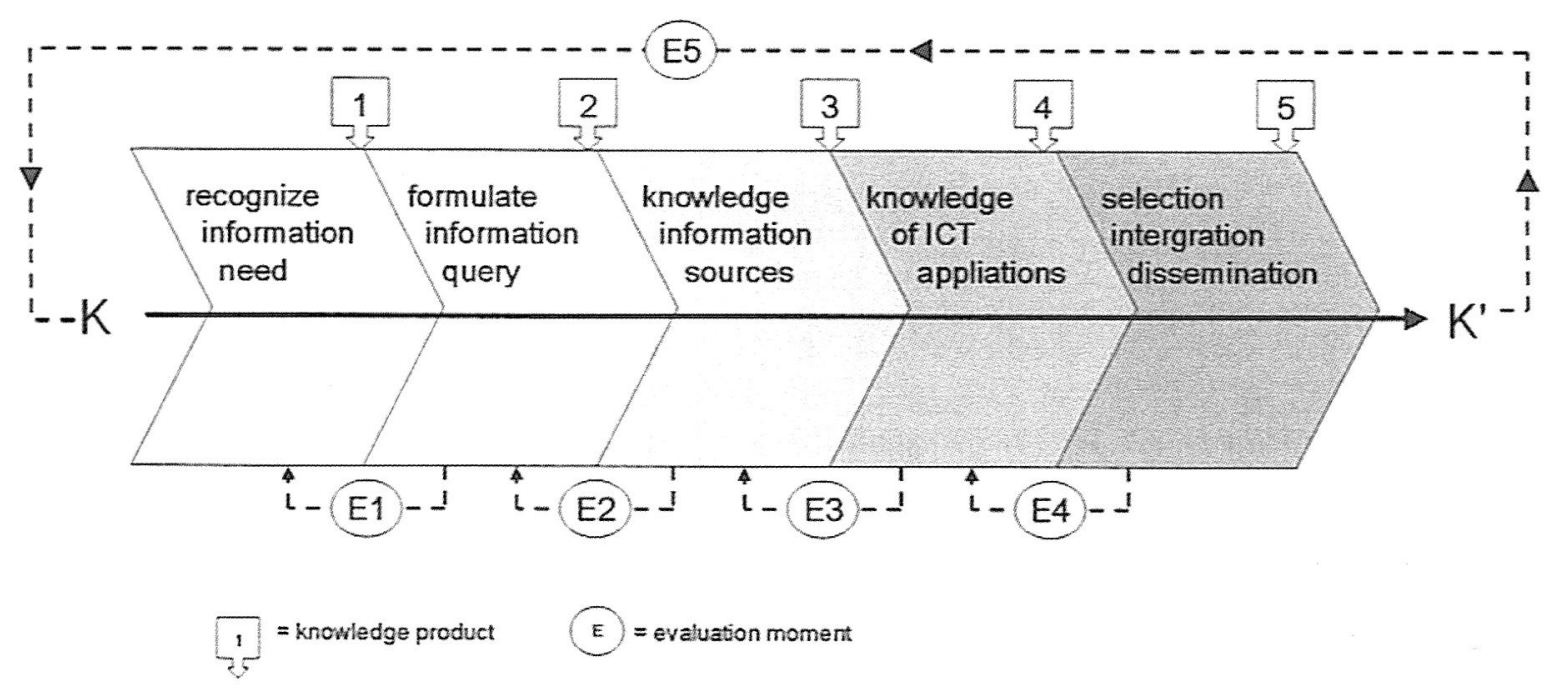

Figure 1. Information literacy model

Although mainly linear in character, information literacy is a complicated process with intermediate loops, and based on the relevance/non-relevancy of information retrieved, adjustments are made. These adjustments are for example the formulation of new search strategies.

Information literacy and information education

Information literacy is normally the product of a process of information education whereby the necessary knowledge, attitudes and skills are acquired. As such it can be viewed as the outcome of the process of information education (Boon, 1990:2).

Information education has the following aims:

- To understand the notion of information

- To create an information awareness and attitude

- To equip individuals with skills and competencies to access and use information

- To create an information culture enabling the effective use of information in society.

Information literacy and the 'hidden curriculum'

Apart from explicit learning according to the established curriculum, the so-called 'hidden curriculum' plays a very important role. According to Illich (1973) many things that are learned at school have hardly anything to do with the formal content of subjects. For example, until the sixties the hidden curriculum taught children that their role in society was to be seen and not to be heard. However, the hidden curriculum is not restricted to behavioural rules. It can also include the learning of skills to use certain technologies.

The hidden curriculum also has a bearing on the teaching of information literacy skills. For example, the development of an effective infostructure at school level (bulletin boards, library, school newspaper, computers, Internet access, school websites, and pupil's home pages) is important because it will expose pupils to an information environment where they will be able to learn (although in an informal way) how to access and use information to function effectively.

It has been argued so far that information literacy is one of the most important skills that are needed in the current era. Information literacy is a product of information education but can also form, in an informal way, an integral part of the so-called hidden curriculum. In the next part of the paper the current status of information literacy at school level in both the Netherlands and South Africa will be explored.

\section{Information Literacy in the Netherlands}

\subsection{The Dutch educational system}

The Netherlands has compulsory education for all children aged five to sixteen years. They begin their school careers at the age of four in primary (BO) or special education (SO). This is followed by secondary education (VO). Students can choose between pre-university (WWO 6 year), senior general secondary (HAVO 5 year), junior general secondary (MAVO 4 year) or pre-vocational (VBO 4 year) education. After the first stage of secondary schooling, pupils move on at around the age of sixteen to secondary vocational education or the second stage of HAVO or WWO. 
Since 1993 the secondary education system has been divided into two phases. The first stage (starting in 1993) of secondary education is called 'Basic Secondary Education' (Basisvorming). This Basic Secondary Education is meant for pupils between the ages of 12 and 15 years and lasts no more than three years. The emphasis is on acquiring skills, which is based on an integrated curriculum.

In August 1998 the 'Second Stage of Secondary Education' was introduced. It is organised according to the concept of 'Place of Study' (Studiehuis = Home of Study). The emphasis is on learning instead of teaching, and pupils are encouraged to take an active, independent approach to learning. Instead of being able to choose whatever combination of subjects they wish, pupils from the fourth year of HAVO and WWO upwards opt for one of the following four subject combinations:

I. culture and society;

2. economics and society;

3. science and health care;

4. science and technology.

3.2 Introduction of ICT and information literacy programs in schools in the Netherlands

ICT (which is here understood in a broader context than just the Internet) was introduced in the 1960s in schools in the Netherlands in response to the enthusiasm of individuals, and the teaching thereof was only done in an informal way. At the end of the 1970s and beginning of the 1980s there was a rapid interest in ICT (specifically the computer) as a social phenomenon. Due to the fact that the Dutch government strives to maintain a leading role in technological developments, large sums of money were made available to schools to acquire computer and related technologies. In the late 1980s computer science had established itself as a separate subject at school level.

Although information literacy (information education) had not yet been formally introduced into the Dutch educational system during the early 1990s, it was taught in an informal way at selected schools. The focus was however more on acquiring ICT related skills than on information literacy skills (Boekhorst \& van Veen, 1996: 134).

\subsection{Subjects}

3.3.I IT Studies (Informatiekunde)

With the introduction of Basic Secondary Education (Basisvorming) in 1993 a new subject, called 'IT studies' (Informatiekunde) was introduced', the main aim being to introduce and orient pupils to the world of informatisation ${ }^{2}$. It comprises five different fields, including data processing, information literacy, data systems and a study of the social impact of information technology on society. Although IT Studies is a compulsory subject, there is no national examination requirement.

\subsubsection{Information technology}

Information technology was accepted as a subject for the Second Stage of Secondary Education. It can be taken as an elective and has the following main objectives:

- to familiarise pupils with the world of computers

- to give a functional understanding of data processing systems, including the organising, processing and distribution of data and

- to acquire insight into the social significance of information technology.

Although there is no central national examination for this subject, there is an internal school examination.

\subsubsection{Other subjects}

A description of ICT is included in most other subjects on the Basic Secondary Education level. Most read more or less as follows:

In the subject Economics ICT is used to process texts, images and numeric data with an emphasis on economic calculating.

In the subject Geography ICT is used to process texts, images and numeric data with an emphasis on (digital) aerial photographs and maps.

I. The Dutch name for the subject is 'Informatiekunde' which means 'knowledge of information'. The Dutch ministry uses in the English version publication on the Dutch school system the word 'IT studies'. This is a good illustration of the approach of the subject as it is further elaborated.

2. One must observe that here informatisation is used in a rather narrow sense, which however is done very frequently, namely the increasing use of computers. We promote the use of the term informatisation in a broader context and precisely for the process in which in a society the production and dissemination of information has become the most important economic activity and in which information and communication technology (ICT) is the basis for economic and social activities and a steering role for further development. (see forthcoming Boekhorst 2004 The Informatisation of Society). 


\subsection{Teaching aids}

ICT training tools were also introduced at an early stage into some schools. The 199I school survey reported I7 different packages used. Most of these products focused on the learning of software skills such as word processing and spreadsheets (Boekhorst \& Van Veen, 1996: 124).

\subsection{School libraries}

School libraries are run fairly individually by schools and there are no formal regulations. A large percentage of school libraries do offer some form of library instruction (library literacy). The instructions vary from a general introduction to the library (explaining how to use the catalogue) to instructions on how to search for and retrieve information. Most of the libraries focus on the use of their own systems and materials (Boekhorst \& Van Veen, 1996: 47).

It is interesting to note that specific emphasis is given to the role of school libraries in the Second Stage of Secondary Education. Two reasons can explain this emphasis. One is the introduction of more computers, with Internet connections, to schools. Libraries are seen as an ideal place to locate these computers. The second reason is that school libraries are increasingly perceived as learning centres where pupils will be able to find and use information for research.

\subsection{Kennisnet}

Kennisnet is a project that was initiated and introduced during 1998 by the Ministry of Education, Culture and Science. It is a computer network that connects all relevant groups in education: pupils, teachers, school management, parents and other relevant organisations. This enables all relevant groups to communicate with one another. The vision is to connect all schools, with the exception of higher education, to this system. At the end of 1999400 schools were already connected. Kennisnet aims to connect an estimated number of 10000 institutions eventually. The following categories of information can be accessed on Kennisnet: teaching materials, school addresses, information on projects, general announcements and discussion groups. The connection itself, the use of the connection and some of the electrical facilities, will be paid for by the ministry (see www.kennisnet.nl).

\section{Information literacy in South Africa}

4.1 The South African educational system

For a proper understanding of the current educational system in South Africa it is important to make some brief comments. The history of education in South Africa is marked by segregation and inadequate schooling for most black people. Since the abolition of Apartheid and the establishment of the Government of National Unity, South African society has been involved in a process of comprehensive political, social and economical change, focusing on the establishment of a non-racial democratic society. This process was confirmed by general elections in 1994 and 1999. Education is considered one of the most important vehicles to achieve not only these political aims but also to make South Africa a leading nation (economic as well as social) in the world.

This implies a radical change in the educational system. The new system empowered the different provinces but also kept a central role for government. To accommodate this, a national Department of Education and nine provincial Departments of Education were established. Thus, in respect of organisation, the education system of South Africa changed from a racially differentiated system to a geographically differentiated system, thereby eliminating some of the duplication of the previous system (Van Wyk, 1998:13). In the discussion of the South African qualifications and educational development it should also be born in mind that several problems (administrative as well as content related) were experienced in the change in the curriculum. There was also a need to delay the introduction due to the fact that some teachers had to develop competencies in many areas.

According to the South African government this new educational system must lead to:

... a strong foundation of general education, the desire and ability to continue to learn, to adapt and develop new knowledge, skills and technologies, to move flexibly between occupations, to take responsibility for personal performance, to set and achieve high standards, and to work co-operatively

(Republic of South Africa, 1995: 15)

This new educational system is in essence outcomes-based. Critical and specific outcomes are distinguished. Critical outcomes focus on general outcomes which will enhance self development within a given social and economic environment. Specific outcomes focus on specific aspects of learning based on specialised fields (Olivier, 1998: 17).

A 'National Qualifications Framework' (NFQ) and the 'South African Qualifications Authority' were established in 1995 to ensure the implementation of the outcomes based education.

The education system comprises of three phases. These are:

- General Education and Training Band

- Further Education and Training Band

- Higher Education and Training Band 
General Education and Training Band can be described as basic education for pupils between the age of seven and sixteen. The Further Education and Training Band comprises a period of three years and can be described as vocational oriented education.

In Table I the new educational structure is given.

Table I National Qualification Framework (ABET = Adult Basic Education and Training)

\begin{tabular}{|c|c|c|c|}
\hline NQF Level & Band & Types of Qualification and Certificates & \\
\hline \multirow[b]{2}{*}{8} & \multirow{7}{*}{$\begin{array}{l}\text { Higher } \\
\text { Education } \\
\text { and } \\
\text { Training Band }\end{array}$} & Doctorates & \\
\hline & & Further Research Degrees & \\
\hline \multirow[b]{2}{*}{7} & & Higher Degrees & \\
\hline & & Professional Qualifications & \\
\hline \multirow[b]{2}{*}{6} & & First Degrees & \\
\hline & & Higher Diplomas & \\
\hline 5 & & $\begin{array}{l}\text { Diplomas, } \\
\text { Occupational Certificates }\end{array}$ & \\
\hline \multicolumn{4}{|c|}{ Further Education and Training Certificates } \\
\hline \multirow[b]{2}{*}{4} & \multirow{6}{*}{$\begin{array}{l}\text { Further } \\
\text { Education } \\
\text { And } \\
\text { Training Band }\end{array}$} & School/College/Training certificates & \\
\hline & & Mix of units from all (NGOs) & \\
\hline & & School/College/Training certificates & \\
\hline 3 & & Mix of units from all (NGOs) & \\
\hline \multirow{2}{*}{2} & & School/College/Training certificates & \\
\hline & & Mix of units from all (NGOs) & \\
\hline \multirow{4}{*}{ I } & General & Senior Phase Grade 7-9 & ABET Level 4 \\
\hline & Education & Intermediate Phase Grade 4-6 & ABET Level 3 \\
\hline & $\begin{array}{l}\text { And } \\
\text { Training Band }\end{array}$ & Foundation Phase Grade I-3 & ABET Level 2 \\
\hline & & Pre-school & ABET Level I \\
\hline
\end{tabular}

\subsection{Introduction of ICT in schools in South Africa}

There was initially no organised effort by educational authorities in South Africa to supply computers and related hardware and software to schools. No official curriculum existed for computer education or information literacy. The introduction of computers and other related information and communication technologies into South African schools was, as in the Netherlands, the result of the enthusiasm of a few people. It was furthermore mainly restricted to private schools.

During the mid-nineties radical changes regarding ICT and education came about. In 1995 the Department of Education organised a conference on ICT and education and this was followed up in 1996 by Technology Enhanced Learning Investigation (TELI). The report focused on several pilot projects pertaining to ICT and education. Of importance is the specific mention of information literacy in one of these projects:

C. Developing a generic information literacy course for use in schools, community centres, industry-based training sites, and other appropriate sites of teaching and learning

(TELI, 1997: 4).

South Africa's blend of first and third worlds is also reflected in the availability and maintenance of ICT. This has a major impact on the ability of schools to introduce and teach ICT skills - even though it might be part of a national curriculum. Some schools do not have electricity or lack the necessary funds to maintain these technologies. This situation is reflected in a shocking report (based on the official Schools Register of Needs) presented to Parliament in September 1997

In the Eastern Cape only 19\% of schools have telephones, Free State $25 \%$ and the Northern Province 32\%.

Compare this with Gauteng (85\%) and the Western Cape (88\%). Less than half the schools in the country have a power supply. In the Northern Province 79\% of schools have no power, in the Eastern Cape 77\%, and Kwazulu-Natal 61\%. In number terms, the Northern Province has 3280 schools without power, whereas in the Western Cape the number is 191.

(Marquard 1998)

Although much has changed during the past seven years, there is still a big difference between the rural schools and schools in the more wealthy townships and cities. 


\subsection{Subjects}

It has already been illustrated that there existed no official curriculum for computer or information literacy in schools in South Africa. Teachers, on an individual level, and with the support of interest groups, developed and introduced computer literacy programmes in some schools. This eventually led to the establishment of Computer Studies as a separate subject at school level. Information literacy as a separate subject was only introduced later at a few selected schools in South Africa (Boekhorst 2000: 148). It was mainly based on existing library instructions and did not form part of an official curriculum. This was confirmed by conversations that the authors had with selected school librarians.

\subsection{Curriculum 2005}

The new educational system in South Africa is organised under the name 'Curriculum 2005' (1997). It is based on the South African Qualifications Authority Act (SAQA) from 1995 and the National Education Policy Act from 1996 (1996). The mission for SAQA is described as follows:

'To ensure the development and implementation of a National Qualifications Framework which contributes to the full development of each learner and to the social and economic development of the nation at large.'(1995:page?)

Curriculum 2005 is based on the philosophy of life-long learning and consists of eight so-called learning areas. These are:

- Language , Literacy and Communication

- Numeracy and Mathematics

- Human and Social Sciences

- Natural Sciences

- Arts and Culture

- Economic and Management Sciences

- Life Orientation

- Technology

\subsubsection{Information literacy}

Although information literacy skills are essential in each of these learning areas, it is of specific importance in the learning areas Language, Literacy and Communication. The following two specific objectives of Language skills have, for example, a bearing on information literacy:

- Learners access, process and use information from a variety of sources and situations.

- Learners use appropriate communication strategies for specific purposes and situations.

The description of Literacy as part of Language, Literacy and Communication learning areas has an even more direct bearing on information literacy. Six different categories of literacy are distinguished. These are:

- Cultural literacy - Cultural, social and ideological values that shape our 'reading' of texts;

- Critical literacy - The ability to respond critically to the intentions, contents and possible effects of messages and texts on the reader;

- Visual literacy - The interpretation of images, signs, pictures and non-verbal (body) language, etc.;

- Media literacy - The 'reading' of media such as TV and film as cultural messages;

- Computer literacy - The ability to use and access information from computers (Curriculum 2005, 1997).

It is striking that information literacy is not mentioned as a separate form of literacy. What makes this more interesting is the fact that information literacy is not a new and unknown phenomenon in South Africa. Authors such as Behrens, Van der Walt, Sayed and others have published substantially on the topic (Behrens 1990, 1991, 1992, 1999; Van der Walt, 1992 Sayed, 1998). One would have expected that it would be listed as one of the categories of literacy in South Africa. The broad definitions of each of these categories however opens the door for interpretation and the possible application of information literacy.

\subsection{School libraries}

School libraries are not separately mentioned in the School Act of 1996. Functional libraries are limited to those schools that have enough resources to fund and manage them. Most schools in South Africa do not have the means to run libraries. The Department of Education is currently considering plans to make libraries more accessible to schools, especially in rural areas (Boekhorst, 2000: 203).

\subsection{SchoolNet SA}

Schoolnet SA is a national organisation that was founded in 1996. It supports schools that want to develop their level of education by offering expertise, coordination and effective partnerships. It aims at creating Learning Communities of Educators and Learners that use ICT.

An outcome of collaboration between government and business, SchoolNet SA has the following objectives: 
- to develop and support the use of ICT in education in South Africa;

- to help address the inequalities of the past;

- to support the introduction of Curriculum 2005;

- to provide communication channels for teachers and learners throughout South Africa; and

- to provide the SchoolMail service, a low-cost E-mail service for all schools with a computer and telephone line.

(See: www.schoolnet.org.za)

\section{Conclusions}

In this article the notion of information literacy and its importance in the information era has been explored. Based on a comparative description between the Dutch and South African educational systems, the following conclusions and findings regarding information literacy and education are drawn by the authors:

- Both governments recognise the importance of preparing their citizens for the challenges of the information age.

- ICT was introduced in the same informal manner at school level in both the Netherlands and South Africa.

- The educational systems in both countries focus much more on computer literacy than on the broader concept of information literacy.

- Libraries can play an important role to enhance information literacy at school level. It is currently undervalued.

- The difference between the Netherlands as a developed country and South Africa as a developing country are quite evident in the allocation of resources to enable information literacy at school level.

- The information infrastructure (school libraries and information networks) provides a very good framework for an effective hidden curriculum pertaining to information literacy.

- The learning areas Language, Literacy, and Communication (depending on interpretation) open the way for the introduction of information literacy programmes as part of the curriculum at school level in South Africa.

\section{References}

American Library Association. 1989. American Library Association Presidential Committee on Information Literacy. Final report. Chigaco: American Library Association.

Behrens, S.J. 1990. Literacy and the evolution towards information literacy: an exploratory study. South African Journal of Llibrary and Information Science 58

Behrens, Shirley Jennifer. 1992. Undergraduate Library and Information Skills in a Distance Learning Environment. Pretoria: University of South Africa.

Behrens, S., Olën, S.I.I. and Machet, M.P. 1999. Mastering information skills. Pretoria: Unisa Press.

Boekhorst, Albert K., and Maarten J.P.van Veen. 1996. Schoolbibliotheken in het voortgezet onderwijs, BBI-reeks. Amsterdam: UvA. Boek- en Informatiewetenschap.

Boekhorst, A.K. 2000. Informatievaardig worden in het onderwijs, een informatiewetenschaplijk perspectief: een vergelijkende gevallenstudie in Nederland en Zuid-Afrika: [s.n], 2000 (http://www.hum.uva.nl/public/prom-akb-tot.pdf).

Boon, J.A. 1990. Broadening horizons: Education for information use. Paper delivered at the pre-conference symposium: Education for optimum information use. SAILIS Conference. (1990: Wild Coast Sun). (Unpublished). I- I2.

Britz, J.J. \& Blignaut, J.N. 200I. Information Poverty and Social Justice. South African Journal of Library and Information Science, 67 (2): 63-69.

Dervin, B., \& Nilan, M. 1986. Information Needs and Uses. In M. E. Williams (Ed.), Annual Review of Information Science and Technology. White Plains, NY: Knowledge Industry Publications : I - 33.

Dumont, A. and Fenoulhet, T. 1997. Towards a Policy Framework for the Knowledge-based Economy. In The Economics of the Information Society edited by Dumort, A. \& Dryden, J. Luxembourg: European Commission, 1997.

Foster, L. 1993: Information literacy: some misgivings. American Libraries, 24 (4): 344-353.

Grulke, W. E. 1997. Life and Work in the Information Age. Johannesburg: Future World, 1997.

Illich, I. D. 1973. Deschooling Society. Harmondsworth: Penquin.

Kennisnet $h t t p: / / w w w . k e n n i s n e t . n l / p o r t a l / h o m e / i n d e x . h t m l$ Available [Online]: Accessed 17 June 2002

Kingma, B.R. 200I. The Economics of Information. A Guide to Economic and Cost-benefit Analysis for Information Professionals. Second edition. Libraries Unlimited: Colorado

Lyotard, J. 1984. The Postmodern Condition: A Report on Knowledge. Minneapolis: University of Minnesota Press.

Marquard, S. 1998. The Internet in the School Curriculum, Internet Technologies and Broadcasting http://www.school.za/research/ sm98a-broadcast.htm last. Available [Online] Access 17 June 2003.

Olivier, C. 1998. How to Educate and Train Outcome Based. Pretoria: Van Schaik.

Swaan, A. 1988. In Care of the State: Health Care, Education and Welfare in Europe and the USA in the Modern Era. Cambridge: Polity Press.

Rifkin, J. 1995. The End of Work. The Decline if the Global Labor Force and the Dawn of the Post-Market Era. G.P. New York: Putman's Sons.

Republic of South Africa (RSA). 1995. White Paper on Education and Training. Cape Town: Parliament.

Republic of South Africa (RSA). 1997. Curriculum 2005, Specific Outcomes, Assessment Criteria, Range Statements, Grades 1 to 9. Discussion Document. Pretoria: Department of Education.

Sayed, Y. 1998. The Segregated Information Highway. Cape Town: University of Cape Town Press.

SchoolNet SA http://www.schoolnet.org.za Available [Online]: Accessed 17 June 2003.

Stiglitz, J. Globalization and its Discontent. New York: Norton Press. 
Swaan, A. 1988. In Care of the State: Health Care, Education and Welfare in Europe and the USA in the Modern Era, Polity Press, Cambridge.

TELI Strategic Planning Committee, 1997. Technology Enhanced Learning Initiative in South Africa: A strategic plan. A Discussion Planning Document Prepared for the Directorate, Pretoria, Department of Education, National Centre for Educational Technology and Distance Education. Pretoria

Van der Walt, M.S. 1992. Onderrig van Inligtingsvaardighede aan Universiteitsstudente. South African Journal of Library and Information Science. 60, (1):39-46

Webster, F. 2002. Theories of the Information Society. Second edition. New York: Routledge.

Wilson, T., \& Walsh, C. 1996. Information Behaviour: an Interdisciplinary Perspective (British Library Research and Innovation Report 10). Boston Spa: British Library Research and Innovation Centre.

Wilterdink, N., \& Heerikhuizen, B. v. 1993. Samenlevingen (3e [herz.] ed.). Amsterdam: Wolters Noordhoff.

Wyk, N. v. 1998. Organisation and Governance of Education in South Africa. In F. Pretorius \& E. M. Lemmer (Eds.), South African Education \& Training: Transition in a Democratic Era Johannesburg: Hodder \& Stoughton: 13 - 24.

Zurkowski, P. G. 1974. The Information Service Environment Relationships and Priorities. Related paper no. 5. National Commission on Libraries and Information Science.

Albert K. Boekhorst is Assistant Professor in the Dept. of Information Studies at the Universiteit van Amsterdam and Visiting Professor at the Dept. of Information Science at the University of Pretoria. Address: Universiteit van Amsterdam, Dept. Information Studies, Oude Turfmarkt I4I, 1012 GC Amsterdam, The Netherlands. 